\title{
Predicted thermal acceptance in naturally ventilated office buildings with double skin façades under Brazilian climates
}

\author{
Authors: Sabrina Barbosa* s.andradebarbosa@gmail.com \\ Kenneth Ip k.ip@brighton.ac.uk
}

*Corresponding author

\begin{abstract}
This study has predicted the annual thermal acceptance levels in naturally ventilated office buildings with double skin façade (DSF) under different Brazilian regional climates. It builds upon the outcomes of a comprehensive research programme on the study of generic thermal performance of naturally ventilated office buildings with DSF, which has identified and evaluated the key design parameters affecting the thermal behaviour of DSF through computational simulation models. Taking into account Brazil's bioclimatic zones characteristics, including the solar incidence and wind conditions, design configurations are adapted, optimised and embedded within computational models for analysis. Thermal acceptance levels of each region, using operative temperatures as the thermal comfort index, are illustrated. The highest levels of thermal acceptance, as high as $90 \%$, are experienced in the south and southeast regions. Around $65 \%$ can be achieved in regions of centre-west, north-west and coastal areas, but only $20 \%$ in the arid region of the north-east. Significance of these thermal acceptance levels is discussed and comparisons to single skin façade (SSF) models highlight the benefits and constraints of the application of the DSF. The methodology and the results developed from this study enable initial assessment of application of DSF in naturally ventilated buildings under warm and hot climates.
\end{abstract}

Keywords: Double skin façade; Thermal acceptance; Natural ventilation; Brazilian climates

\section{Highlights}

- DSF simulation models optimised for each bioclimatic zone in Brazil are developed

- Ventilation strategies with DSF in different regions of Brazil are identified

- Three representative regional thermal acceptance levels are established: $90 \%, 65 \%$ and $20 \%$

- Correct specification of design parameters and implementation of appropriate control strategy are paramount in achieving good thermal acceptance 


\section{Introduction}

The double skin façade (DSF) is an architectural element that has gained recognition as a potential solution for reducing air conditioning loads of highly glazed office buildings. It consists of an additional fully glazed external skin installed over the conventional building façade, forming a normally ventilated air cavity between the layers (Oesterle et al., 2001). The technology was originally developed for low energy buildings in European and other localities with moderate climates in order to enable the reduction of winter heating loads (Saelens, 2002). However, the early design often resulted in summer overheating that instigated research and development of remedial features such as sun protection devices, modification of façade geometry and cavity ventilation schemes in order to achieve effective thermal performance even during the hot summer periods (Gratia and De Herde, 2004b; Eicker et al., 2008). The demonstrated ability of the DSF to reduce cooling loads has motivated its recent adoption by designers in many cities located in warm and even hot climates as showcases of iconic corporate buildings associated with sustainability. These impetuses triggered a number of studies on viability and implementation of DSF in countries with warmer climates such as in China (Zhang et al., 2010), Spain (Torres et al., 2007) and Singapore (Chou et al., 2009). Most of these studies are based on building models that are fully air-conditioned without considering further exploitation of the technology to enhance the energy performance through incorporation of natural ventilation to operate under a mixed mode ventilation strategy (Barbosa and Ip, 2014).

Although there is a growing interest to take advantage of the environmental and energy benefits of natural ventilation in buildings with DSF, the lack of performance prediction has been considered as a key barrier for its implementation especially in utilising the climate driven functionalities (Darkwa et al., 2014). To fill this gap of knowledge, and in particular addressing the growing building and economic developments in warm and tropical climate countries such as Brazil, a comprehensive research programme that investigated the influences of generic architectural configurations and climatic conditions on the thermal 
performance of naturally ventilated buildings with DSF has been developed (Barbosa and Ip, 2014; Barbosa et al., 2015a; b). The findings from these studies enabled this current and more detailed study on predicting the levels of annual thermal acceptance in naturally ventilated office buildings with DSF in different regions of Brazil. The paper introduces the concept of DSF and provides the background on previous studies and relevant outcomes accomplished that underpin the methodology developed in the current study. The characteristics of regionals climates are classified and applied to simulations models which are individually optimised and adapted to the specific climatic conditions showing the predicted annual thermal acceptance levels. The findings support designers to assess the potential of DSF at the early stage of design.

\section{Double skin façade in naturally ventilated buildings}

The DSF can be regarded as a type of chimney attached to a building that can promote the natural ventilation using solar induced thermal buoyancy force and air pressure resulted from the effects of wind acting on the building surfaces. Thermal stack and wind effects seldom act in isolation so the magnitude and pattern of natural air movement through the building depends on the strength and direction of these combined natural driving forces and the resistances of the flow paths (CIBSE, 2005).

Fundamentally, with reference to Figure 1, part of the shortwave solar radiations incident on the DSF is absorbed by the materials of the inner and outer layers of the façade. A portion of this radiation is converted into heat energy and stored in the materials, thereby raises its temperature. Part of this heat energy is subsequently transferred to the air in the cavity by convection and long wave radiations. The air in the cavity becomes then hotter and lighter than its surrounding environment resulting in air movement towards the top of the façade (Pérez-Grande et al., 2005). 


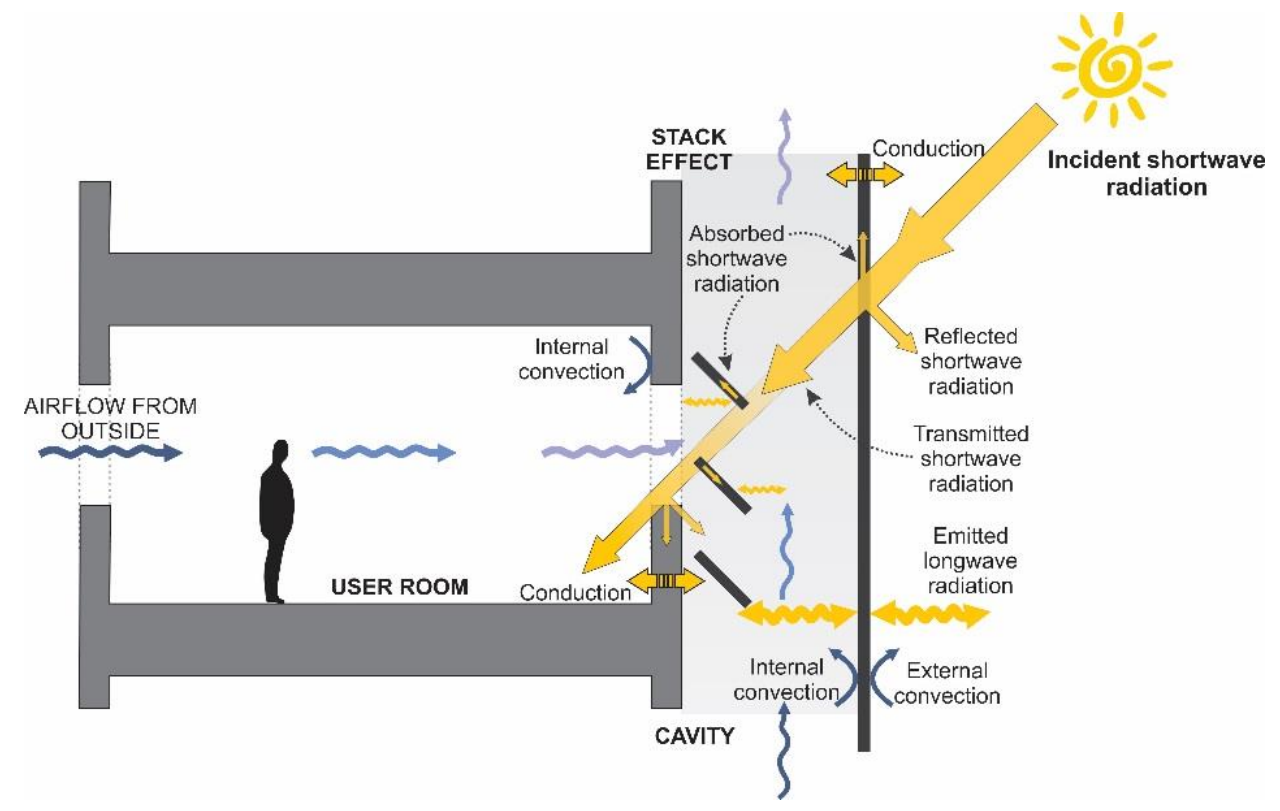

Figure 1 - Heat transfer and airflows in the DSF and the adjacent office

In naturally ventilated buildings air from the user room displaces the cavity air while fresh air from outdoor is drawn through openings on the opposite façade, which passes through the user space before being extracted into the cavity. The air in the cavity is further heated by the solar gains forming a continuous convection stream, as illustrated in Figure 1, (Ding et al., 2005; Radhi et al., 2013).

The airflow in such thermal chimney can be quantified by the following empirical equation (ASHRAE, 2009):

$$
\left.\mathrm{Q}=\mathrm{C}_{\mathrm{D}} \mathrm{A} \sqrt{2 \mathrm{~g} \Delta \mathrm{H}_{\mathrm{NPL}}\left(\mathrm{t}_{\mathrm{i}}-\mathrm{t}_{\mathrm{o}}\right) / \mathrm{t}_{\mathrm{i}}} \quad \text { (Equation } 1\right)
$$

Where: $\mathrm{Q}=$ air flow rate, $\mathrm{m} 3 / \mathrm{s} ; \mathrm{A}=$ area of the opening, $\mathrm{m} 2 ; \mathrm{CD}=$ discharge coefficient of the opening; $\mathrm{g}=$ acceleration due to gravity, $\mathrm{m} / \mathrm{s} 2 ; \Delta \mathrm{HNPL}=$ vertical distance from the neutral pressure line $(\mathrm{NPL})$ to the aperture, $\mathrm{m}$; $\mathrm{ti}=$ air temperature in cavity (higher temperature), $\mathrm{K}$; to $=$ outdoor temperature (lower temperature), $\mathrm{K}$. This equation shows that in buildings with DSF, the key variables determining the thermal airflow through a building are the cavity height and cross-sectional area, the position and area of the window's openings and the temperature difference between the air inside the cavity and the external air. Secondary and interacting factors such as the building compartmentation, the thermal 
properties of building fabric and glazing, and the internal heat gains may affect how the heat is exchanged and the consequent path of airflow in the building.

Another important parameter that contributes to the resulting air movement within the building is the wind effect that varies according to the external surface pressures acting across the building envelope (ASHRAE, 2013b). The airflows in the cavity reach their minimum when the wind direction is parallel to the façade but they increase when perpendicular, especially if the DSF is located at the leeward side of the building, which reinforces the cavity's stack effect (Gratia and De Herde, 2004a; Lou et al., 2012). As weather files are often based on data measured from open spaces, it is important to consider that temperatures may vary in urban central areas, which tend to experience higher temperatures due to the nature of materials usually applied to buildings and roads. It is also important to note that the local wind speed and direction may be affected by the density and height of constructions or topography surrounding the building (e.g. open country or city centre). Slower speeds will in reality occur relative to the quoted meteorological wind speed in dense terrains. The wind can be redirected by obstacles such as topography or large vertical constructions which can have significant effect on the wind speed profile. Additionally, street canyons may modify wind magnitude and direction and therefore, wind pressure coefficients experienced in different building faces can either pronounce or decrease the airflow through the building.

The key drawback of DSFs is their high investment, the design and installation costs had been reported to be as much as $60-80 \%$ higher than conventional façades (Andresen, 2002). Additionally, cleaning, operation, inspection, servicing and maintenance costs also contribute to higher costs relative to the single skin facades, however, some studies have demonstrated their potential cost efficiency over a longer period of time with higher level of durability (Ghaffarianhoseini et al., 2016).

\section{Previous and current studies}


This study builds upon the outcomes of a comprehensive research programme on the prediction of the thermal performance of naturally ventilated buildings with DSF. Their relevance to this study can be described under 4 stages.

\subsection{Stage 1 - Critical literature review}

A systematic critical review of the existing body of literature from the last decade on experimental and computational simulation of DSFs was performed and disseminated by Barbosa and Ip (2014). The study identified the key design and site parameters that influence the thermal performance of the DSF and projected their effects when applied to naturally ventilated buildings. The site parameters are dominated by the external solar incidence, wind directions and the corresponding speeds. The design parameters consist of physical configurations of the building, the two skins of the façade and ventilation openings as well as additional design features. Seven design parameters are considered significant namely the cavity depth, bottom cavity ventilation opening, window positions, shading device, inner skin material, cavity extension and window sizes - which are illustrated in figure 4 .

\subsection{Stage 2 - Building model development: from base case to optimized case}

A base case model was developed as a reference building prototype for evaluating the influence of different design and site parameters on the thermal performance of building with DSF. The building geometry and windows area are based on a topology study of office buildings in Brazil by Carlo (2008). Materials selected for the fabric components, mainly based on the ABNT (2003), are commonly used in Brazil. U values that commensurate with modern office buildings for case study comparisons are selected. The thermal specification is higher than typical Brazilian construction so may incur additional costs. The occupancy density was defined as medium capacity, which is 14 people per $100 \mathrm{~m}^{2}$, as indicated by the regulation for Brazilian design parameters (ABNT, 1980). 
The base case model consists of an 11 storey open plan office building with dimensions of $12 \mathrm{~m} \times 16 \mathrm{~m}$ and $3.5 \mathrm{~m}$ floor-to-floor height with horizontal windows placed at mid-height of the floor with WWR of $50 \%$ on both south and north façades were incorporated to the model. The longest sides face north/south orientations with horizontal windows located at midheight of the floor. A clear single glazing outer layer was applied to the north face forming an air cavity of $50 \mathrm{~cm}$. Table 1 shows the building model fabric material properties and the description of internal heat gains applied during the office occupancy hours (from 8 a.m. to 6 p.m.) for the whole year.

Table 1 - Building model fabric materials characterisation and description of internal heat gains

\begin{tabular}{|c|c|c|c|c|c|}
\hline & \multicolumn{3}{|c|}{$\begin{array}{l}\text { Description of building fabric materials } \\
\text { (from outside to inside) }\end{array}$} & Thickness & $\begin{array}{l}\text { Overall } \\
\mathrm{U} \text { value } \\
{\left[\mathrm{W} /\left(\mathrm{m}^{2} \cdot \mathrm{K}\right)\right]}\end{array}$ \\
\hline$\stackrel{\frac{\infty}{N}}{3}$ & \multicolumn{3}{|c|}{$\begin{array}{l}\text { Internal plaster }(2.5 \mathrm{~cm})+\text { Ceramic block }(9.0 \mathrm{~cm})+\text { Thermal } \\
\text { insulation: stone wool }(2.5 \mathrm{~cm})+\text { Ceramic block }(9.0 \times 14.0 \times 24.0 \\
\mathrm{cm})+ \text { Internal plaster }(2.5 \mathrm{~cm})+\text { External painting }(\alpha=0.3)\end{array}$} & $27 \mathrm{~cm}$ & 0.61 \\
\hline ড্் & \multicolumn{3}{|c|}{$\begin{array}{l}\text { Stone chippings }(1 \mathrm{~cm})+\text { Felt and bitumen layers }(0.5 \mathrm{~cm}) \\
\text { Concrete }(15 \mathrm{~cm})+\text { Insulation material: glass fibre quilt }(20 \mathrm{~cm})+ \\
\text { Cavity }(5 \mathrm{~cm})+\text { Ceiling tiles }(1 \mathrm{~cm})\end{array}$} & $42 \mathrm{~cm}$ & 0.18 \\
\hline $\begin{array}{l}\text { 을 흔 } \\
\text { 인 은 }\end{array}$ & \multicolumn{3}{|c|}{$\begin{array}{l}\text { Clay }(75 \mathrm{~cm})+\text { Brickwork }(25 \mathrm{~cm})+\text { Cast concrete }(10 \mathrm{~cm})+ \\
\text { Insulation material: Dense EPS }(5 \mathrm{~cm})+\text { Chipboard }(5 \mathrm{~cm}) \\
\text { Synthetic carpet }(1 \mathrm{~cm})\end{array}$} & $121 \mathrm{~cm}$ & 0.28 \\
\hline \multicolumn{6}{|c|}{ Internal gains } \\
\hline & People & Equipment & \multicolumn{2}{|l|}{ Lighting (500lux) } & Total \\
\hline & $\begin{array}{c}9.8\left[\mathrm{~W} / \mathrm{m}^{2}\right] \\
70 \mathrm{~W} / \text { person) }\end{array}$ & $8.4\left[\mathrm{~W} / \mathrm{m}^{2}\right]$ & $18.7\left[\mathrm{~W} / \mathrm{m}^{2}\right]$ & \multicolumn{2}{|c|}{$36.9\left[\mathrm{~W} / \mathrm{m}^{2}\right]$} \\
\hline
\end{tabular}

The airflow distribution through north windows of the rooms of the base case scenario is indicated in Figure 4.2, in which the positive values indicate airflows moving away from the offices towards the cavity, whereas the negative values represent reverse flows. The mean annual net airflows for each floor is shown in Figure 4.3, which also presents the mean annual airflows entering the cavity though the bottom and leaving it through the top outlet. The diagrams show the occurrence of reverse flow on the top floor, represented by the negative net airflow. 


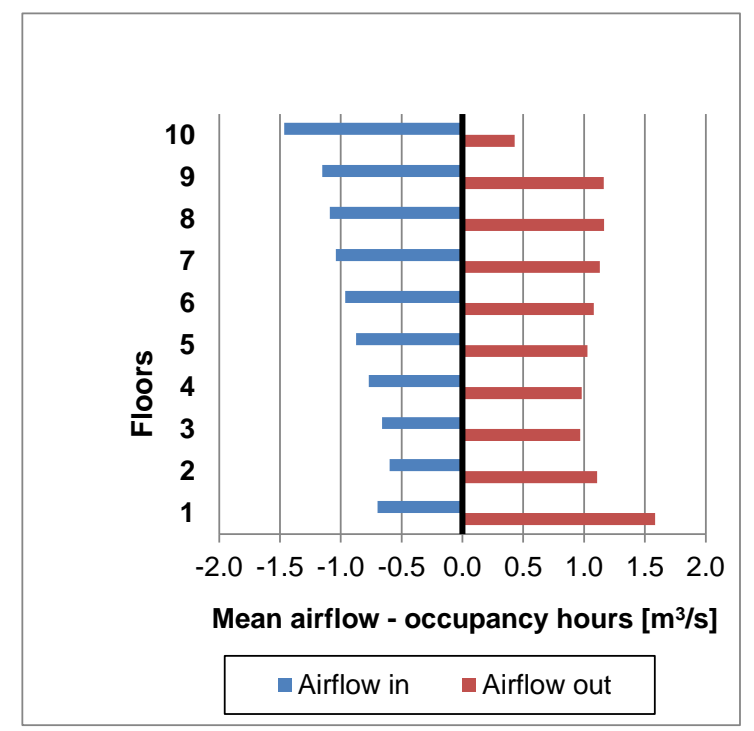

Figure 2 - Annual mean airflows in and out of each floor for the base case

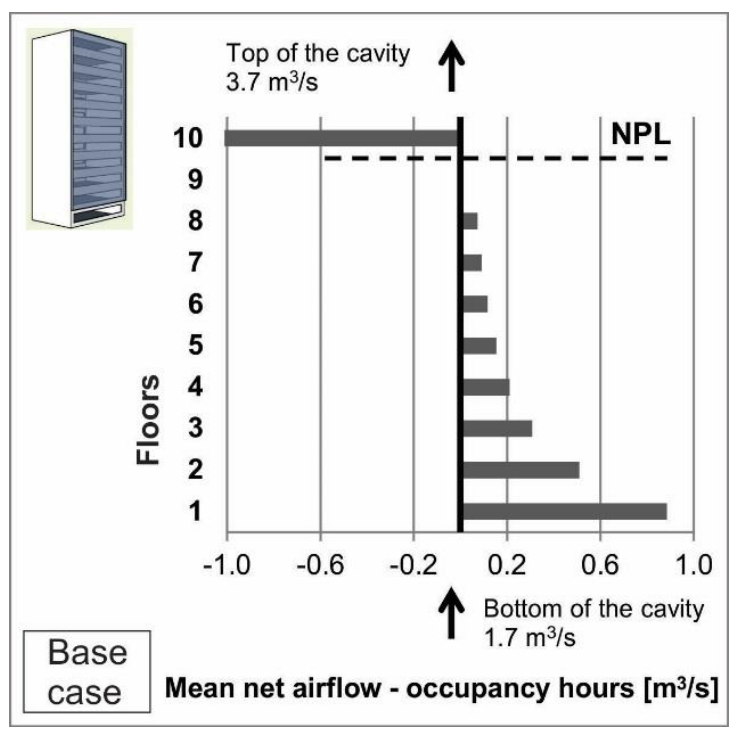

Figure 3 - Annual mean net airflow for each floor for the base case

The airflow profile distribution over the floors is a result of the pressure differences at different levels of the building. The driving pressure at the first floor level is greater than that at the second, which is correspondingly greater than that at the third, due to the difference in height between the inlet and outlet openings. Thus, net airflows across each floor gradually reduce from 1st level up to the neutral pressure line (NPL). For the base case scenario, the NPL occurs on the 9th floor and the net airflow changes from the cavity towards the occupied space on the 10th floor, where the pressure in the cavity is higher than the adjacent office space.

The design and site parameters identified at stage 1 were applied to the base case model to evaluate their individual and combined influences on the thermal performance of the building with DSF. Alternative case scenarios, which took into account not only the quantitative variations but considered the limitations on practical implementation, were modelled and examined using the thermal dynamic simulation software IESVE (2014). The typical features of a model optimised to maximise the effect of natural ventilation consist of a straight DSF, cavity depth of $1 \mathrm{~m}$ and extension of $3.5 \mathrm{~m}$ above the roof. Windows are sized to achieve balanced flow rates across all floors and air buoyancy force is enhanced by concrete 
shading device in the cavity (Barbosa et al., 2015b). The process of applying the key design parameters to the base case leading to the optimised model is illustrated in Figure 4.

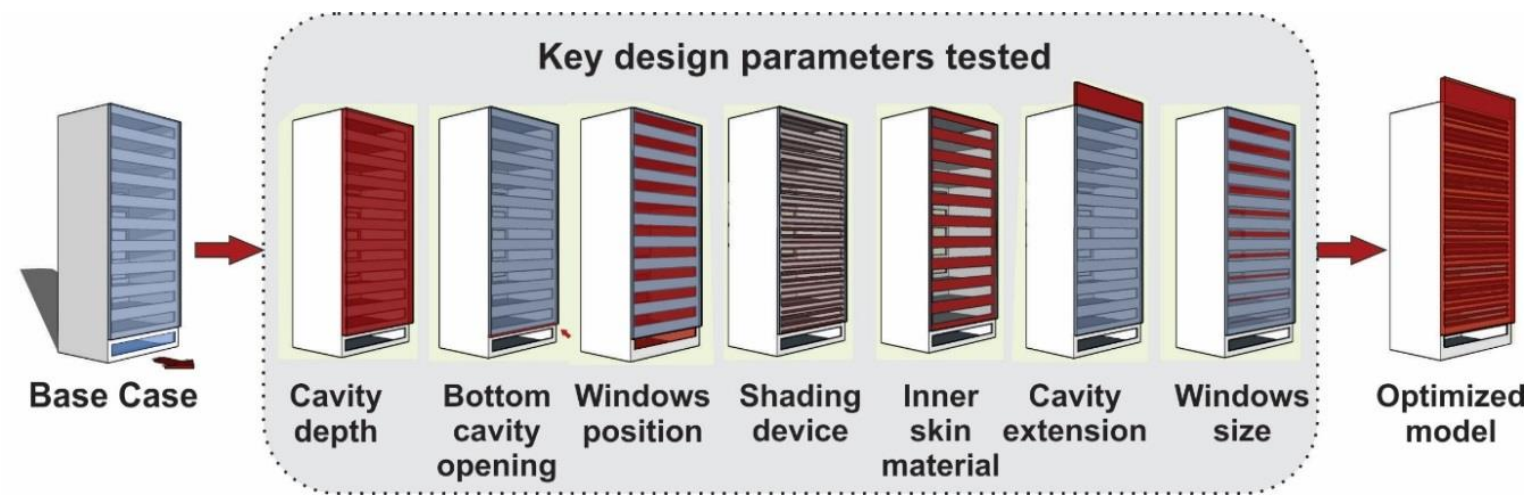

Figure 4-Design parameters applied in developing the optimized model

Results of the base case and some of the alternative cases performed on the dynamic simulation software IESVE were compared to steady state 'snap shot' results of CFD simulations from Flovent. Due to the complexity of the physical phenomena involved in the DSF behaviour, qualitative results of cases performed on IESVE were compared to CFD results with focus on the resulting airflow profile across the floors when different design solutions were modified from the base case.

Due to the great number of cells required for the entire building, the solution was limited by the computational resources available. In order to maintain the solution for all the building floors, the depth of the CFD building model was reduced to a representative section of $1 \mathrm{~m}$ length. This allowed the modelling of all building floors combined with the application of a fine grid definition to improve the resolution of the calculations and the accuracy of the results. The internal heat gains included on each floor were calculated for $1 \mathrm{~m}$ length of the building model.

Figure 5 presents the CFD results of the base case model. Similarly to the results by IESVE model, the airflow gradually decreases on the upper floors of the building indicating the that pressure distributions across the building levels was effectively estimated by IESVE.

On the other hand, there is a clear difference of airflow on the top of the building between the IESVE and CFD models, as the last did not present reverse airflow from cavity towards 
the room. This can be explained by the nature of the CFD simulation, in which thermal mass is saturated with solar heat in a steady state model pronouncing the buoyancy force within the cavity and the consequent suction of air from the rooms. Additionally, in the CFD simulation, the transient condition of the exterior air temperature is not considered and the case is simulated under a stable external environmental condition. Another possible reason for this effect is that the reduced length of the cavity may have increased the stack effect within it by concentrating and directing the flow of air towards the top of the cavity. This increased the buoyancy force in relation to the IESVE model, in which the full length of the façade is modelled. Although both software are widely accepted in the industry and the research community, this partial verification process has enhanced the confidence of the results generated from the simulation.

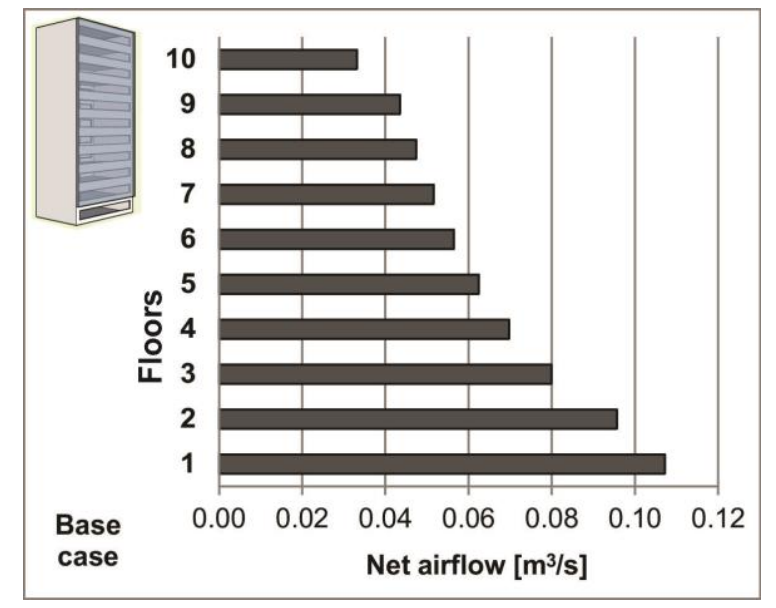

Figure 5 - Results of base case model simulated on FloVENT

\subsection{Stage 3 - Influence of site parameters on the DSF thermal performance}

At this stage, the effect of site parameters identified in stage 1 on the dynamic thermal performance is tested on the optimized models developed from stage 2. A zonal airflow model is developed for simulating airflows and natural ventilation, including air movement driven by wind and buoyancy induced pressures. The building model exposure was set to an urban and suburban surrounding context in which low height spaced obstructions are present in the adjacent sites. 
The annual thermal comfort performances of the models tested under different external thermal conditions were evaluated using the ASHARE-55 (2013a) thermal comfort model. The influence of wind pressures acting on the building façades at different orientations were further examined which could be improved by as much as $300 \%$ on the upper floors.

Variations of wind direction and its speed are affected by the sites conditions such as terrain surrounding the building and lower than quoted meteorological wind speed are expected in dense terrains.

\subsection{Stage 4 -Current study: thermal acceptance under Brazilian climates}

This stage of the research focuses on investigating the viability of the DSF operation under Brazilian weather conditions. Details are reported in the following sections.

\section{Methodology}

Bioclimatic zones representing Brazilian climates were first identified and their respective climatic characteristics and data necessary for analysing the influence of site parameters were established. Thermal acceptance criteria based on the thermal acceptability limits of ASHARE-55 (2013a) - Thermal Environmental Conditions for Human Occupancy - were defined. Computational models were developed with reference to the design and the site parameters described in section 3.2. The thermal acceptance levels of the models with DSF under the Brazilian bioclimatic zones were derived from the simulations results from IESVE. Furthermore, models of case study building with only a single skin façade (SSF) were also tested and the results were compared with DSF models.

\subsection{Brazilian bioclimatic zones}

Brazil, situated between the parallels of $5^{\circ} 16^{\prime} 19^{\prime \prime}$ latitude north and $33^{\circ} 45^{\prime} 09^{\prime \prime}$ latitude south, presents a wide range of climate conditions that vary from the relatively cooler southern region to the tropical climates in the central and northern coastal areas. A climate classification system proposed by the Brazilian Association of Technical Standards (2003) is 
adopted for this study. It divides the territory into eight relatively homogeneous climate areas, as shown in Figure 6, which are defined according to the local climate characteristics of 330 cells across Brazil.

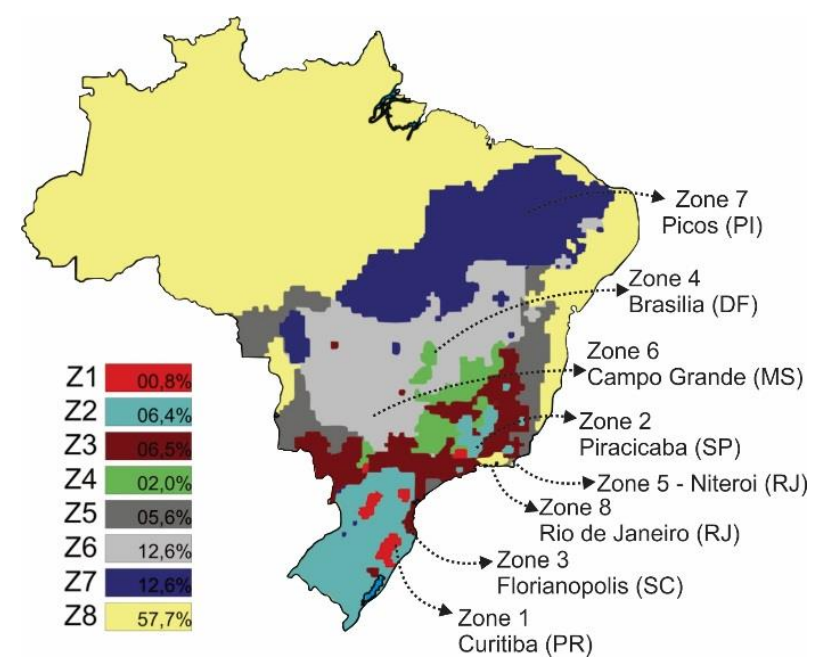

Figure 6 - Map of Brazil showing the eight bioclimatic zones

Representative cities of each bioclimatic zone, which are the state capitals or cities with the highest number of habitants were used in the simulations. They are: Curitiba-PR (zone 1), Piracicaba-SP (zone 2), Florianopolis-SC (zone 3), Brasilia-DF (zone 4), Niteroi-RJ (zone 5), Campo Grande-MS (zone 6), Picos-PI (zone 7) and Rio de Janeiro-RJ (zone 8). The weather data used are based on the test reference year (TRY) databases obtained from the US department of energy and from the energy efficiency laboratory of the Federal University of Santa Catarina. General descriptions of the climatic conditions in these zones and the passive strategies recommended by Givoni (1992) for non-air-conditioned buildings (Schuch et al., 2010) are presented in Table 2. The occupancy density in the current study has been defined as medium capacity. Other cases of higher internal loads may increase the internal air temperatures which may need additional solutions such as night ventilation and use of thermal mass materials. 
Table 2 - Key climatic characteristics of each representative city studied

\begin{tabular}{|c|c|}
\hline Zone/City & General climatic characteristics \\
\hline $\begin{array}{c}1 \\
\text { Curitiba }\end{array}$ & $\begin{array}{l}\text { Zone Location: Zone } 1 \text { is mainly localized in the south region of Brazil and is } \\
\text { characterized by the occurrence of the lowest temperatures among the zones. } \\
\text { Average temperatures - Summer: } 20.7^{\circ} \mathrm{C} \text {; Winter: } 14.0^{\circ} \mathrm{C} \\
\text { Average humidity - Summer: } 85 \% \text {; Winter: } 83 \% \\
\text { Main passive strategy recommended: Solar heating, especially during winter. } \\
\text { Predominant wind: Mainly distributed between from east and east southeast. }\end{array}$ \\
\hline $\begin{array}{c}2 \\
\text { Piracicaba }\end{array}$ & $\begin{array}{l}\text { Zone Location: The zone occurs predominantly in the south and southwest areas. } \\
\text { Average temperatures - Summer: } 22.9^{\circ} \mathrm{C} \text {; Winter: } 19.0^{\circ} \mathrm{C} \\
\text { Average humidity - Summer: } 79 \% \text {; Winter: } 67 \% \\
\text { Main passive strategy recommended: Solar heating in winter and cross natural } \\
\text { ventilation in summer, which is required on average } 40 \% \text { of the time. } \\
\text { Predominant wind: Predominantly from east and southeast. }\end{array}$ \\
\hline $\begin{array}{c}3 \\
\text { Florianopolis }\end{array}$ & $\begin{array}{l}\text { Zone Location: The zone is mainly localized in south region. } \\
\text { Average temperatures - Summer: } 24.5^{\circ} \mathrm{C} \text {; Winter: } 17.5^{\circ} \mathrm{C} \\
\text { Average humidity - Summer: } 83 \% \text {; Winter: } 82 \% \\
\text { Main passive strategy recommended: Cross ventilation is the main passive strategy } \\
\text { suggested, especially during the summer, which is required on average } 67 \% \text { of the time. } \\
\text { Predominant wind: Mostly from north. }\end{array}$ \\
\hline $\begin{array}{c}4 \\
\text { Brasilia }\end{array}$ & $\begin{array}{l}\text { Zone Location: The zone is mainly localized in the centre west region. } \\
\text { Average temperatures - Summer: } 22.5^{\circ} \mathrm{C} \text {; Winter: } 20.8^{\circ} \mathrm{C} \\
\text { Average humidity - Summer: } 76 \% \text {; Winter: } 56 \% \\
\text { Main passive strategy recommended: Passive solar heating is recommended in autumn } \\
\text { and winter and selective cross ventilation in summer, for about } 30 \% \text { of the time. } \\
\text { Predominant wind: Mainly from east. }\end{array}$ \\
\hline $\begin{array}{c}5 \\
\text { Niteroi }\end{array}$ & $\begin{array}{l}\text { Zone Location: The zone is present in some areas of the southeast and the centre west } \\
\text { regions. } \\
\text { Average temperatures - Summer: } 24.5^{\circ} \mathrm{C} \text {; Winter: } 20.6^{\circ} \mathrm{C} \\
\text { Average humidity - Summer: } 78 \% \text {; Winter: } 74 \% \\
\text { Main passive strategy recommended: Cross ventilation is recommended all over the } \\
\text { year, more than } 30 \% \text { of the time from November to May. } \\
\text { Predominant wind: Mainly from south. }\end{array}$ \\
\hline $\begin{array}{r}6 \\
\text { Cam } \\
\text { Gran }\end{array}$ & $\begin{array}{l}\text { Zone Location: Cities in zone } 6 \text { are mainly localized in the centre west of the country. } \\
\text { Average temperatures - Summer: } 25.3^{\circ} \mathrm{C} \text {; Winter: } 22.7^{\circ} \mathrm{C} \\
\text { Average humidity - Summer: } 77 \% \text {; Winter: } 61 \% \\
\text { Main passive strategy recommended: Cross natural ventilation, which is recommended } \\
\text { for } 26 \% \text { of the year, and evaporative cooling. } \\
\text { Predominant wind: Mostly divided between from north and east. }\end{array}$ \\
\hline $\begin{array}{c}7 \\
\text { Picos }\end{array}$ & $\begin{array}{l}\text { Zone Location: It is present in the arid region of the northeast. } \\
\text { Average temperatures - Summer: } 27.9^{\circ} \mathrm{C} \text {; Winter: } 28.1^{\circ} \mathrm{C} \\
\text { Average humidity - Summer: } 68 \% \text {; Winter: } 47 \% \\
\text { Main passive strategy recommended: Air conditioning, especially during the summer, } \\
\text { and natural ventilation, which is recommended for } 39 \% \text { of the time. } \\
\text { Predominant wind: Mainly distributed from northeast to southeast. }\end{array}$ \\
\hline $\begin{array}{l}\text { Rio de } \\
\text { Janeiro }\end{array}$ & $\begin{array}{l}\text { Zone Location: The zone covers the north region and most of the coastal areas } \\
\text { Average temperatures - Summer: } 26.5^{\circ} \mathrm{C} \text {; Winter: } 21.7^{\circ} \mathrm{C} \\
\text { Average humidity - Summer: } 77 \% \text {; Winter: } 78 \% \\
\text { Main passive strategy recommended: Permanent natural ventilation is recommended } \\
\text { for } 61 \% \text { of the year, but mechanical cooling is not discarded. } \\
\text { Predominant wind: Well distributed from all directions. }\end{array}$ \\
\hline
\end{tabular}




\subsection{Model adaptation}

Based on previous findings on the influence of the site parameters on the DSF thermal performance in different climatic zones (Barbosa et al., 2015a), simulation models were appropriately configured to optimise their thermal performance. Considerations included the inclusion/exclusion of shading devices, selection of DSF orientation in relation to solar incidence, dominant wind and control of windows opening according to exterior temperatures. Other parameters such as the type of exposure of the building to the surrounding terrain and height of the openings were incorporated to determine the representative models for the simulation and analyses. Table 3 highlights the key features of the models simulated with brief descriptions of their justification.

All models were simulated with DSF orientated to the north to maximise the utilization of solar radiation. Models for bioclimatic zones 2 and 4 were additionally simulated with DSF orientated to the west, at the leeward side of the dominant wind direction, to evaluate any beneficial effect on airflow rates through the building, which are especially needed during the summer. For bioclimatic zones 6 and 7, which experience high temperatures, although there is a prevalence of wind from the east, simulation with DSF facing west was discarded in order to avoid high solar heat gains during the hottest periods of the day.

For bioclimatic zones 1 to 4, which experience mild and low temperatures, especially during the winter, opening profiles set to respond the outdoor temperatures are applied to the air intake windows opposite to the DSF in order to control airflows and to avoid high levels of discomfort during cold outdoor conditions. The window opening regulators were set to start to open the south windows when the outside temperature was above $16^{\circ} \mathrm{C}$ and modulated the degree of opening linearly until it was fully opened at $20^{\circ} \mathrm{C}$. The north windows and the top of the cavity were set as open the whole time to maintain some ventilation flow, even in cold days, as indicated in Figure 7. For bioclimatic zone 5, the window opening profiles were applied when windows were orientated perpendicular to the dominant wind. For zones 6,7 
and 8 , windows remained open the whole time since high external temperatures dominate in those regions.

\section{South windows \\ Top of the cavity and North windows}

\section{Tout $>16^{\circ} \mathrm{C} \rightarrow$ windows start to open $<$ Tout $20^{\circ} \mathrm{C}>$ windows fully open}

\section{Windows open the whole time}

Figure 7-Diagram of windows opening profile

Table 3-Key features of DSF and SSF models tested

\begin{tabular}{|c|c|c|c|c|}
\hline $\begin{array}{l}\text { Biocli- } \\
\text { matic } \\
\text { zone }\end{array}$ & $\begin{array}{l}\text { Façad } \\
\text { e type }\end{array}$ & Orientation & $\begin{array}{l}\text { Window } \\
\text { opening } \\
\text { control }\end{array}$ & Justification of models tested \\
\hline \multirow{3}{*}{$\begin{array}{l}\overline{0} \\
\stackrel{0}{0} \\
\text { N }\end{array}$} & \multirow[b]{2}{*}{ DSF } & North & Yes & \multirow{3}{*}{$\begin{array}{l}\text { Considering the lower external temperatures of this } \\
\text { city, two cases with DSF facing north, with and } \\
\text { without shading devices, which allow higher solar } \\
\text { heat gains into the offices, were tested. }\end{array}$} \\
\hline & & $\begin{array}{l}\text { North (no } \\
\text { shading device) }\end{array}$ & Yes & \\
\hline & SSF & North and south & Yes & \\
\hline \multirow{4}{*}{$\begin{array}{l}N \\
\stackrel{0}{0} \\
\stackrel{0}{0}\end{array}$} & \multirow{2}{*}{ DSF } & North & Yes & \multirow{4}{*}{$\begin{array}{l}\text { In order to take advantage of the full potential of } \\
\text { ventilation over the day, a north orientated DSF } \\
\text { was tested. Additionally, a case with DSF } \\
\text { orientated to the west, at the leeward side of wind } \\
\text { direction was also tested as this increases airflow } \\
\text { rates in the building, which would be required } \\
\text { during the summer. }\end{array}$} \\
\hline & & West & Yes & \\
\hline & \multirow[b]{2}{*}{ SSF } & North and south & Yes & \\
\hline & & East and west & Yes & \\
\hline \multirow{3}{*}{$\begin{array}{l}m \\
\stackrel{0}{0} \\
\stackrel{0}{0}\end{array}$} & \multirow{2}{*}{ DSF } & North & No & \multirow{3}{*}{$\begin{array}{l}\text { The model was simulated with DSF orientated to } \\
\text { north as not only it was the most effective } \\
\text { orientation to improve stack effect during the day, } \\
\text { but the prevailing wind direction could reinforce the } \\
\text { cavity stack effect. Considering the winter mild } \\
\text { climate conditions, two cases with and without } \\
\text { windows opening control were tested. }\end{array}$} \\
\hline & & North & Yes & \\
\hline & SSF & North and south & Yes & \\
\hline \multirow{4}{*}{$\begin{array}{l}+ \\
\stackrel{\Xi}{\Xi} \\
\stackrel{0}{0}\end{array}$} & \multirow{2}{*}{ DSF } & North & No & \multirow{4}{*}{$\begin{array}{l}\text { A model with DSF facing north was tested in order } \\
\text { to take advantage of the stack effect to promote } \\
\text { natural ventilation in the building, considering the } \\
\text { low wind speeds characteristics of the city. } \\
\text { Additionally, as the predominant wind direction was } \\
\text { from the east, another case in which the DSF was } \\
\text { facing west was tested. }\end{array}$} \\
\hline & & West & Yes & \\
\hline & \multirow[b]{2}{*}{ SSF } & North and south & Yes & \\
\hline & & East and west & Yes & \\
\hline \multirow{2}{*}{ 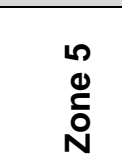 } & DSF & North & Yes & \multirow{2}{*}{$\begin{array}{l}\text { To take advantage of both the wind and stack } \\
\text { effects, a model with DSF orientated to north was } \\
\text { tested in order to meet the demands for cross } \\
\text { ventilation all year round. }\end{array}$} \\
\hline & SSF & North and south & Yes & \\
\hline \multirow{3}{*}{$\begin{array}{l}0 \\
\stackrel{0}{0} \\
\stackrel{0}{0} \\
\text { N }\end{array}$} & \multirow{2}{*}{ DSF } & North & No & \multirow{3}{*}{$\begin{array}{l}\text { To combine the benefits of the ventilation promoted } \\
\text { by buoyancy effect of the DSF and the wind } \\
\text { pressures, a case with DSF orientated to the north } \\
\text { was tested. Additionally, a model with DSF } \\
\text { orientated to the south was also evaluated as the } \\
\text { ventilation could be improved when DSF was at the } \\
\text { leeward side of the wind direction. }\end{array}$} \\
\hline & & South & No & \\
\hline & SSF & North and south & No & \\
\hline
\end{tabular}




\begin{tabular}{|c|c|c|c|c|}
\hline \multirow{3}{*}{$\begin{array}{l}\hat{\Phi} \\
\stackrel{0}{0} \\
\stackrel{0}{N}\end{array}$} & \multirow{2}{*}{ DSF } & North & No & \multirow{3}{*}{$\begin{array}{l}\text { A case with DSF facing north was tested with the } \\
\text { view that the stack effect ventilation could be } \\
\text { promoted by the DSF. Cases with DSF orientated } \\
\text { to the east or west were discarded to avoid glazing } \\
\text { areas on those orientations, as it might increase } \\
\text { solar heat gains into the user rooms. }\end{array}$} \\
\hline & & East & No & \\
\hline & SSF & North and south & No & \\
\hline \multirow{2}{*}{ 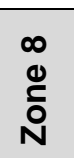 } & DSF & North & No & \multirow{2}{*}{$\begin{array}{l}\text { Considering the variability of wind directions, a } \\
\text { case with DSF facing north was tested in order to } \\
\text { take advantage of stack effect promoted by the } \\
\text { DSF. }\end{array}$} \\
\hline & SSF & North and south & No & \\
\hline
\end{tabular}

\subsection{Evaluation of thermal acceptance}

The standard ASHARE-55 (2013a), which uses the adaptive approach to consider the indoor acceptable temperature as a function of the outdoor air temperature, provided a suitable method for establishing the indicator for predicting the thermal acceptance levels of naturally ventilated buildings under Brazilian climate conditions. Adapting the change in outdoor air temperatures, the standard defines a wider but more realistic comfort range of operative temperatures within which occupants will adapt and adjust their feeling of thermal comfort. The evaluation is based on typical of office work, with metabolic rates ranging from 1.0 to 1.3 met, and occupants may freely adapt their clothing to the indoor and/or outdoor thermal conditions within a range at least as wide as $0.5-1.0$ clo. The operative temperature used in the standard is defined mathematically by the following equation (ASHRAE, 2009), where Ti is the indoor air temperature $\left[{ }^{\circ} \mathrm{C}\right], \operatorname{Tr}$ is the mean radiant temperature $\left[{ }^{\circ} \mathrm{C}\right]$, and $\mathrm{v}$ is the air speed $[\mathrm{m} / \mathrm{s}]$.

$$
T_{o p}=\frac{t_{i} \sqrt{10 v}+T_{r}}{1+\sqrt{10 v}}
$$

Acceptability limits for typical building applications, in which the thermal comfort range satisfies $80 \%$ of people, are represented by the following equations:

- Lower temperature limit $\left(\mathrm{T}_{\mathrm{LTL}}\right.$ in $\left.{ }^{\circ} \mathrm{C}\right): \quad \mathrm{T}_{\mathrm{LTL}}=0.31 * \mathrm{~T}_{\text {out }}+14.3$ (equation 2)

- Upper temperature limit $\left(\mathrm{T}_{\mathrm{UTL}}\right.$ in $\left.{ }^{\circ} \mathrm{C}\right): \quad \mathrm{T}_{\mathrm{UTL}}=0.31 * \mathrm{~T}_{\text {out }}+21.3 \quad$ (equation 3 ) 
$\mathrm{T}_{\text {out }}$ is the mean outdoor air temperature, which is calculated by the average of daily mean temperature of the previous 15 days.

The standard allows the upper acceptability temperature limit to increase based on the Standard Effect Temperature (SET) method when the room air speed is above $0.3 \mathrm{~m} / \mathrm{s}$. In such case, the modified acceptable temperature limits are calculated according to the corresponding air speed, as shown in Table 4.

Table 4 - Increase in acceptable operative temperature limits at air speed increase above $0.3 \mathrm{~m} / \mathrm{s}$.

\begin{tabular}{|c|c|c|}
\hline Air speed $=\mathbf{0 . 6 m} / \mathrm{s}$ & Air speed $=\mathbf{0 . 9 m} / \mathrm{s}$ & Air speed $=1.2 \mathrm{~m} / \mathrm{s}$ \\
\hline $1.2^{\circ} \mathrm{C}$ & $1.8^{\circ} \mathrm{C}$ & $2.2^{\circ} \mathrm{C}$ \\
\hline
\end{tabular}

\section{Results and discussions}

The results are summarised under three distinct groups - cold, mild and hot climaticcovering all the climate zones identified in section 4.1. To provide a clear representative illustration, only the results of thermal acceptance of the $5^{\text {th }}$ floor are plotted on the ASHRAE (2013a) thermal comfort diagram. Each group presents the predicted thermal acceptability levels for each model simulated and compares the findings. A table at the end of each group is used to summarise the thermal acceptance results for the cases tested.

\subsection{Cold climate regions (Bioclimatic zones 1, 2 and 3)}

Figure 8 shows operative temperatures for the case with shading device simulated under bioclimatic zone 1. Curitiba city presented $90 \%$ of thermal acceptability, i.e. $80 \%$ of people will accept the thermal conditions in the naturally ventilated building with DSF during $90 \%$ of the $t$ working hours. The removal of shading devices marginally decreased the periods of thermal discomfort as higher solar heat gains increase the office air temperature during winter.

Figure 9 shows the thermal acceptability for the DSF facing north simulated under bioclimatic zone 2 . It reached $84 \%$ over the year with the most uncomfortable periods 
occurring due to hot conditions, especially from September to March. For the case with DSF orientated to the west, a slight increase of discomfort due to excessively high temperatures was observed. Although the predominantly perpendicular wind direction reinforces the stack effect within the cavity, the increase in operative temperatures can be explained by the higher solar heat gains during the afternoons.

The cases simulated under bioclimatic zone 3 demonstrated that when DSF is orientated to the north, annual thermal acceptability can reach about $92 \%$. The case in which south windows remain open the whole time presented $17 \%$ more uncomfortable hours due to colder conditions than the case with window openings with control. This demonstrates that regulation of airflow is needed under cold outdoor conditions. Figure 10 presents the operative temperatures for the case simulated under bioclimatic zone 3 in which the window opening profile was applied to the south windows. Most of the discomfort moments are due to hot conditions, which account for $7 \%$ of the time, especially in January and February.

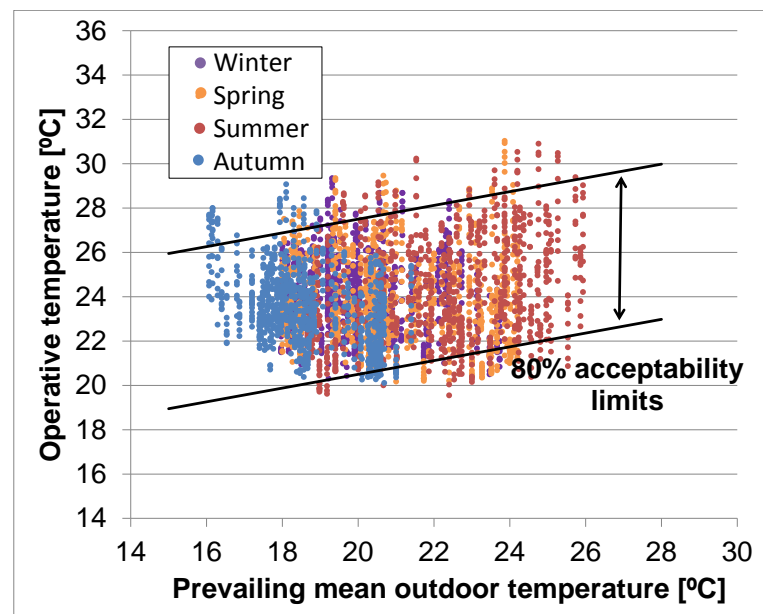

Figure 8 - Annual operative temperatures of optimized model under bioclimatic zone 1

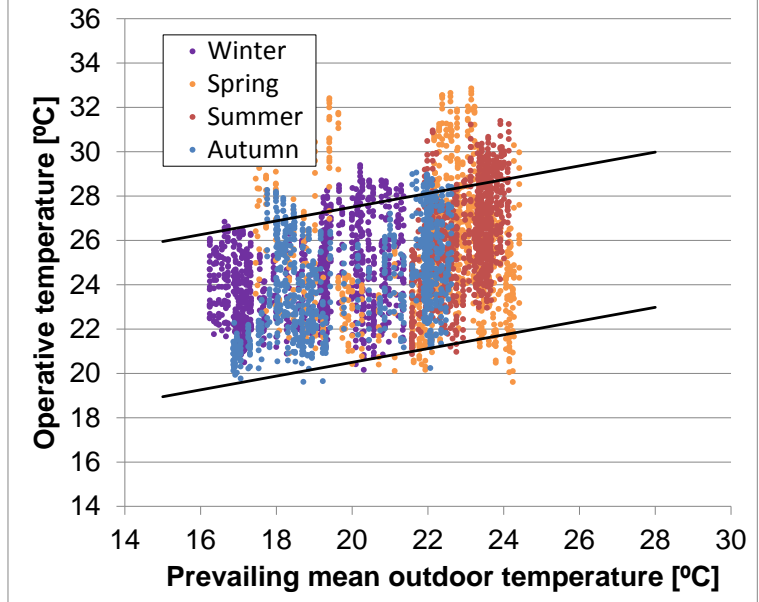

Figure 9 - Annual operative temperatures of optimized model under bioclimatic zone 2 


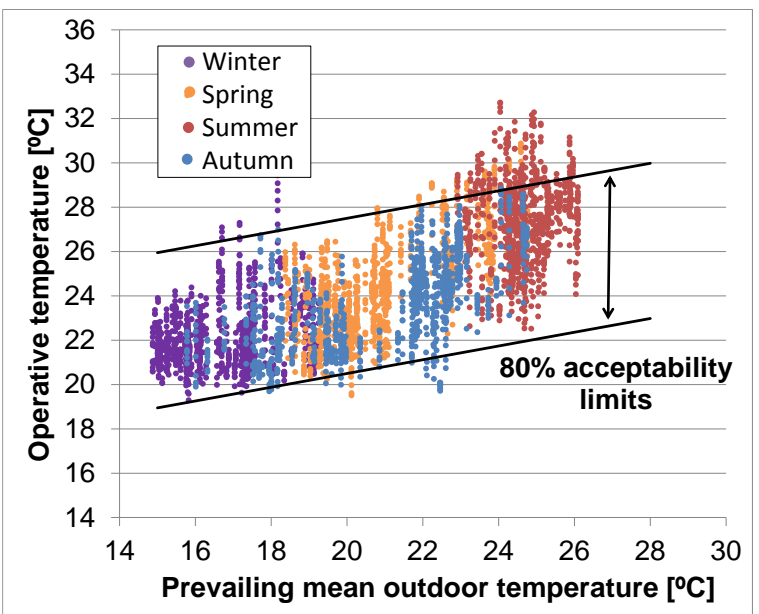

Figure 10 - Annual operative temperatures of optimized model under bioclimatic zone 3

For these coldest bioclimatic zones 1, 2 and 3, the results demonstrate that due to the low temperatures in the winter, the application of the window opening profile according to the outside temperature can improve the thermal acceptance. Furthermore, when defining the DSF orientation, not only the wind prevailing directions must be considered, but also adequate solar protection, as it has a considerable influence on overheating during the hottest periods.

\subsubsection{Comparison with SSF}

The SSF cases simulated under the coldest bioclimatic zones of the country indicated that these cases presented approximately $10 \%$ more uncomfortable periods due to colder indoor conditions than DSF case in the winter. Table 5 compares the results for the DSF and SSF models for bioclimatic zones 1, 2 and 3 .

Table 5-Summary of thermal acceptance of all cases for bioclimatic zones 1, 2 and 3

\begin{tabular}{|c|c|c|c|c|c|c|}
\hline \multirow{2}{*}{$\begin{array}{c}\text { Bioclimatic } \\
\text { Zone }\end{array}$} & \multirow{2}{*}{$\begin{array}{l}\text { Façade } \\
\text { type }\end{array}$} & \multirow{2}{*}{ Orientation } & \multirow{2}{*}{$\begin{array}{l}\text { Windows } \\
\text { opening } \\
\text { control }\end{array}$} & \multicolumn{3}{|c|}{ Thermal acceptance (\%) } \\
\hline & & & & Too cold & Comfortable & Too hot \\
\hline \multirow{3}{*}{1} & \multirow[b]{2}{*}{ DSF } & North & Yes & 8 & 89 & 3 \\
\hline & & $\begin{array}{l}\text { North (no shading } \\
\text { device) }\end{array}$ & Yes & 5 & 90 & 5 \\
\hline & SSF & North and south & Yes & 20 & 77 & 3 \\
\hline \multirow{4}{*}{2} & \multirow{2}{*}{ DSF } & North & Yes & 2 & 84 & 14 \\
\hline & & West & Yes & 1 & 80 & 19 \\
\hline & \multirow{2}{*}{ SSF } & North and south & Yes & 6 & 78 & 16 \\
\hline & & East and west & Yes & 10 & 78 & 13 \\
\hline 3 & DSF & North & No & 18 & 75 & 7 \\
\hline
\end{tabular}




\begin{tabular}{|l|l|l|c|c|c|c|}
\hline & & North & Yes & 1 & 92 & 7 \\
\cline { 2 - 6 } & SSF & North and south & Yes & 16 & 81 & 2 \\
\hline
\end{tabular}

\subsection{Mild climate regions (Bioclimatic zones 4 and 5)}

In Bioclimatic zone 4, the cases with DSF facing north presented 7\% less hours of 'too hot' conditions than the case with west facing DSF. Although the predominant wind reinforces the cavity stack effect when it is west orientated, the high levels of solar heat gains during the afternoon decreases the periods of thermal comfort. Figure 11 presents the annual operative temperatures for the case in which DSF is facing west. Although uncomfortable temperatures are experienced all over the year, the spring season presents the highest levels of hot conditions.

The model simulated under bioclimatic zone 5 presented $92 \%$ annual thermal acceptance (Figure 12). The uncomfortable moments due to hot conditions occur mainly during January and February, although unacceptable temperatures occur for only $15 \%$ of the time during the summer (from December to March). September is the month with the highest levels of uncomfortable conditions, which reaches approximately $12 \%$ of the time due to the lowest temperatures experienced during that period.

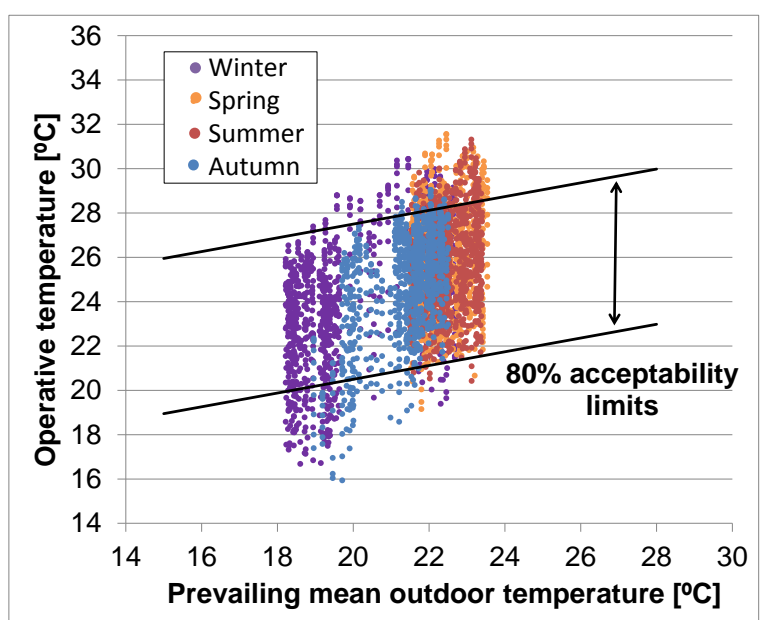

Figure 11 - Annual operative temperatures of optimized model under bioclimatic zone 4

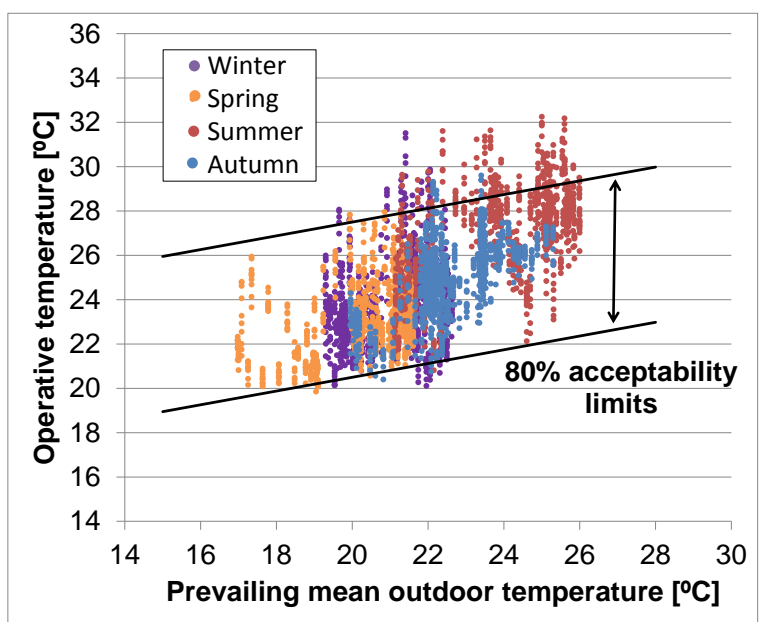

Figure 12 - Annual operative temperatures of optimized model under bioclimatic zone 5 


\subsubsection{Comparison with SSF}

The single skin case simulated under bioclimatic zone 4 presented similar thermal acceptability as the model with DSF. However, the SSF case simulated under bioclimatic zone 5 presented $10 \%$ higher levels of thermal discomfort due to cold conditions from the predominant wind perpendicular to the window openings. This indicates that for climates with mild temperatures over the year and hot summers, there is little or no improvements in thermal performance during the summer with the addition of the second skin, however, periods of thermal discomfort during winter is reduced. A comparison of the thermal acceptance levels for bioclimatic zones 4 and 5 are presented in Table 6.

Table 6 - Summary of thermal acceptance of all cases for bioclimatic zones 4 and 5

\begin{tabular}{|c|c|c|c|c|c|c|}
\hline \multirow{2}{*}{ Zone } & \multirow{2}{*}{$\begin{array}{c}\text { Façade } \\
\text { type }\end{array}$} & \multirow{2}{*}{ Orientation } & \multirow{2}{*}{$\begin{array}{l}\text { Windows } \\
\text { opening } \\
\text { control }\end{array}$} & \multicolumn{3}{|c|}{ Thermal acceptance (\%) } \\
\hline & & & & Too cold & Comfortable & Too hot \\
\hline \multirow{4}{*}{4} & \multirow{2}{*}{ DSF } & North & No & 5 & 84 & 11 \\
\hline & & West & Yes & 0 & 81 & 18 \\
\hline & \multirow{2}{*}{ SSF } & North and south & Yes & 5 & 85 & 10 \\
\hline & & East and west & Yes & 6 & 84 & 10 \\
\hline \multirow{2}{*}{5} & DSF & North & Yes & 1 & 92 & 7 \\
\hline & SSF & North and south & Yes & 11 & 85 & 4 \\
\hline
\end{tabular}

\subsection{Hot climate regions (Bioclimatic zones 6, 7 and 8)}

For bioclimatic zone 6, the results indicated that although similar thermal acceptance levels, of approximately $57 \%$, were achieved for the orientations tested, the model with DSF facing south presented $5 \%$ more uncomfortable temperatures due to 'too hot' conditions than the case with DSF orientated to the north. When DSF is south orientated, the wind forces are the main ventilation driver through the building, whereas when the DSF is north orientated, not only the DSF stack effect drives the airflow, but there is also a contribution from wind effects. Figure 13 shows the annual operative temperatures according to the seasons when DSF is north orientated. The moments of discomfort due to excessive heat account for $35 \%$ of the time with the lowest unpleasant moments occurring from May to July. 
Figure 14 shows the results for the case with DSF facing north simulated under bioclimatic conditions of zone 7 . Acceptance levels of only $20 \%$ were achieved in the model and no cold conditions were indicated due to the very high outdoor temperatures throughout the year. The models under bioclimatic zone 7 presented the lowest thermal acceptability throughout the year showing inappropriate conditions for the use of naturally ventilated buildings with DSF.

The model simulated under bioclimatic zone 8 presented $71 \%$ of thermal comfort acceptance (Figure 15) with the lowest levels occurring from January to March, when the discomfort due to hot conditions reaches more than $60 \%$. With the distributed wind directions over the year, there are moments in which wind pressures reinforce the stack effect but also moments in which they lessen the natural ventilation in the building.

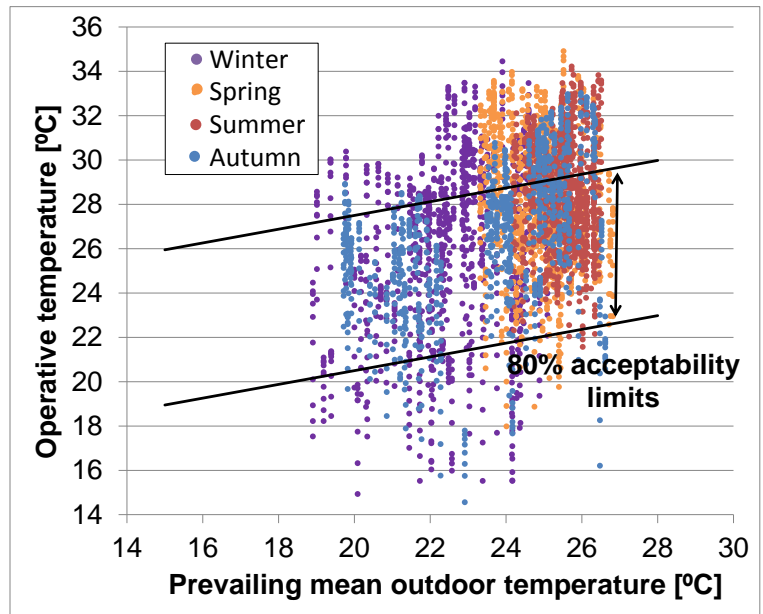

Figure 13 - Annual operative temperatures of optimized model under bioclimatic zone 6

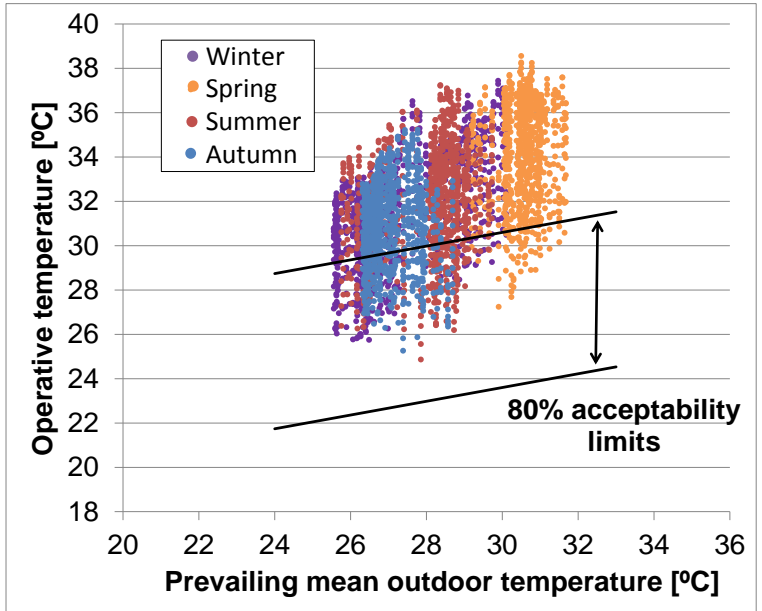

Figure 14 - Annual operative temperatures of optimized model under bioclimatic zone 7

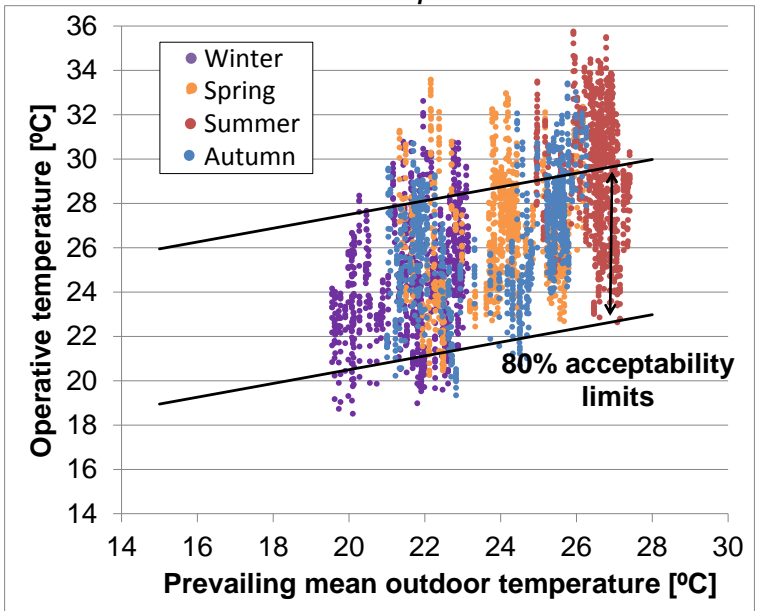

Figure 15 - Annual operative temperatures of optimized model under bioclimatic zone 8 


\subsubsection{Comparison with SSF}

In hot and tropical climates of zones 6 and 8 , the models predicted thermal acceptance levels of around $65 \%$, which can be explained by periods of high temperatures occurring all over the year. Although night time ventilation, shading devices and fully open south windows were included in the DSF models in bioclimatic zones 6 and 8, these cases presented more periods of 'too hot' conditions when compared to single skin models, approximately $10 \%$ and $5 \%$, respectively. This can be explained by the decrease in air speed in the room due to greater air resistance created by the second skin. Table 7 compares the percentages of thermal acceptance over the working hours for the cases simulated under bioclimatic zones 6, 7 and 8 .

Table 7 - Summary of thermal acceptance of all cases for bioclimatic zones 6, 7 and 8

\begin{tabular}{|c|c|c|c|c|c|c|}
\hline \multirow{2}{*}{ Zone } & \multirow{2}{*}{$\begin{array}{c}\text { Façade } \\
\text { type }\end{array}$} & \multirow{2}{*}{ Orientation } & \multirow{2}{*}{$\begin{array}{l}\text { Windows } \\
\text { opening } \\
\text { control }\end{array}$} & \multicolumn{3}{|c|}{ Thermal acceptance (\%) } \\
\hline & & & & Too cold & Comfortable & Too hot \\
\hline \multirow{3}{*}{6} & \multirow{2}{*}{ DSF } & North & No & 7 & 58 & 35 \\
\hline & & South & No & 5 & 55 & 40 \\
\hline & SSF & North and south & No & 11 & 63 & 26 \\
\hline \multirow{3}{*}{7} & \multirow{2}{*}{ DSF } & North & No & 0 & 20 & 80 \\
\hline & & East & No & 0 & 19 & 81 \\
\hline & SSF & North and south & No & 0 & 24 & 76 \\
\hline \multirow{2}{*}{8} & DSF & North & No & 4 & 71 & 25 \\
\hline & SSF & North and south & No & 8 & 72 & 20 \\
\hline
\end{tabular}

\section{Conclusions}

This study evolves through the development of a comprehensive research programme on the thermal performance of naturally ventilated buildings with double skin façade (DSF). It has predicted the annual levels of thermal acceptance under different regional Brazilian climates based on optimized models that have taken into consideration the characteristics of the bioclimatic zones and the influence of the building and site parameters on the DSF's thermal behaviour. Knowledge gained from previous studies, such as the inclusion of shading devices, orientations and application of window operation profile, enabled informed 
selection and definition of DSF functionalities to the simulation models appropriate to specific climatic regions.

For the regions of the south of Brazil, the results indicate that thermal acceptability levels of up to $90 \%$ can be achieved when DSF is north oriented. In those cases, a mixed mode ventilation strategy operating in conjunction with the mechanical air conditioning system will reduce discomfort on the extreme hot days. In the centre west, coastal and north areas of the country, the cooling potential of natural ventilation promoted by DSF is limited to the cooler seasons, but during the hot seasons, the cases with DSF presented slightly lower thermal acceptability when compared to single skin models. Therefore, this technology will not benefit the building thermal performance. In these cases, individual analyses considering the local climatic conditions and the design concepts are recommended for the definition of the DSF application. For the regions with the lowest acceptance levels, mainly located in the hot arid region in the northeast, the DSF is not appropriate although there may be reduction in the cooling load.

This study has highlighted the complexity of applying DSF technology to buildings. To accomplish successful outcomes not only requires correct design details but also appropriate operation of the systems - such as controlling the opening and closure of windows. The results and methodology developed from this study serve as a general guide to support designers at the early design stage who are considering using DSF in naturally ventilated buildings in warm and hot climates. It is important to note that the assumptions and the limitations related to the computational models are unlikely to capture the exact usage, occupancy profiles, climate and site conditions of another building, therefore, extrapolation of results may not be appropriate and where possible representative models should be developed and analysed.

Studies on DSF can still be considered at its infancy, more research in developing detailed computational models working in parallel with validation through experimental and site measurements is certainly necessary not only to enhance the credibility of the results from 
computer simulation but also enabling testing of novel design concepts in order to further

exploit their functionalities.

\section{References}

ABNT 2003. Thermal performance in buildings - Brazilian Bioclimatic Zones and Building Guidelines for Low-Cost Houses. Brazilian National Standards Organization.

ABNT, B. A. O. T. S. 1980. Air-conditioning system - Central air units - Basic parameters for design Procedure. Brazilian National Standards Organization.

I. ANDRESEN, "Dobbeltfasader (double-skin facades)," SINTEF Technol.Soc. Rep. no. STF22 A01016, Trondheim, Norway, 2002

ASHRAE 2013a. ASHRAE 55 - Thermal Environmental Conditions for Human Occupancy. Atlanta: Ame.

ASHRAE 2013b. Handbook-Fundamentals. Atlanta, GA: American Society of Heating, Refrigerating and Air Conditioning Engineers.

BARBOSA, S. \& IP, K. 2014. Perspectives of double skin façades for naturally ventilated buildings: A review. Renewable and Sustainable Energy Reviews, 40, 1019-1029.

BARBOSA, S., IP, K. \& SOUTHALL, R. Influence of key site parameters on the thermal performance of double skin façades in naturally ventilated buildings in a tropical climate. In: CUCINELLA, M., PENTELLA, G., FAGNANI, A. \& D’AMBROSIO, L., eds. 31st International PLEA Conference, 2015a Bologna. Ass. Building Green Futures, Bologna.

BARBOSA, S., IP, K. \& SOUTHALL, R. 2015b. Thermal comfort in naturally ventilated buildings with double skin façade under tropical climate conditions: The influence of key design parameters. Energy and Buildings, 109, 397-406.

CARLO, J. C. 2008. Desenvolvimento de Metodologia de Avaliação da Eficiência Energética do Envoltório de Edificações Não-residenciais. Doctoral, Federal University of Santa Catarina (In portuguese).

CHOU, S. K., CHUA, K. J. \& HO, J. C. 2009. A study on the effects of double skin façades on the energy management in buildings. Energy Conversion and Management, 50, 2275-2281.

CIBSE 2005. Applications Manual AM10. Natural ventilation in non-domestic buildings. Great Britain: Chartered Institution of Building Services Engineers (CIBSE).

DARKWA, J., LI, Y. \& CHOW, D. H. C. 2014. Heat transfer and air movement behaviour in a doubleskin façade. Sustainable Cities and Society, 10, 130-139.

DING, W., HASEMI, Y. \& YAMADA, T. 2005. Natural ventilation performance of a double-skin façade with a solar chimney. Energy and Buildings, 37, 411-418.

EICKER, U., FUX, V., BAUER, U., MEI, L. \& INFIELD, D. 2008. Façades and summer performance of buildings. Energy and Buildings, 40, 600-611.

GHAFFARIANHOSEINI, A., GHAFFARIANHOSEINI, A,. BERARDI, U., TOOKEY,J., LI, D. \& KARIMINIA, S. 2016. Exploring the advantages and challenges of double-skin façades (DSFs). Renewable and Sustainable Energy Reviews, 60, 1052-1065.

GRATIA, E. \& DE HERDE, A. 2004a. Is day natural ventilation still possible in office buildings with a double-skin façade? Building and Environment, 39, 399-409.

GRATIA, E. \& DE HERDE, A. 2004b. Natural cooling strategies efficiency in an office building with a double-skin façade. Energy and Buildings, 36, 1139-1152.

IESVE 2014. Integrated Environmental Solutions. Integrated Environmental Design Solutions Ltd

LOU, W., HUANG, M., ZHANG, M. \& LIN, N. 2012. Experimental and zonal modeling for wind pressures on double-skin façades of a tall building. Energy and Buildings, 54, 179-191.

OESTERLE, E., LIEB, R.-D., LUTZ, M. \& HEUSLER, W. 2001. Double Skin Façades - Integrated Planning, Munich, Prestel.

PÉREZ-GRANDE, I., MESEGUER, J. \& ALONSO, G. 2005. Influence of glass properties on the performance of double-glazed façades. Applied Thermal Engineering, 25, 3163-3175.

RADHI, H., SHARPLES, S. \& FIKIRY, F. 2013. Will multi-façade systems reduce cooling energy in fully glazed buildings? A scoping study of UAE buildings. Energy and Buildings, 56, 179-188.

SAELENS, D. 2002. Energy Performance Assessments of Single Storey Multiple-Skin Façades. PhD, Catholic University of Leuven.

SCHUCH, M., MATUSO, C. A., BUDAG, K. H. \& ONO, E. T. 2010. Analysis Bio. Laboratory of Energy Efficiency in Buildings 
TORRES, M., ALAVEDRA, P., GUZMÁN, A., CUERVA, E., PLANAS, C., CLEMENTE, R. \& ESCALONA, V. Double skin façades - Cavity and exterior openings dimensions for saving energy on Mediterranean climate. Building Simulation, 2007 Beijing, China.

ZHANG, Y., WANG, J., CHEN, H., ZHANG, J. \& MENG, Q. 2010. Thermal comfort in naturally ventilated buildings in hot-humid area of China. Building and Environment, 45, 2562-2570. 